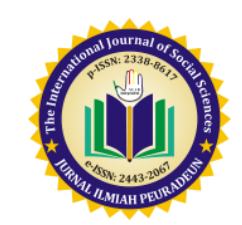

\title{
THE EFFECTS OF PSYCHOEDUCATIONAL METHODS ON COLLEGE STUDENTS' ATTITUDES TOWARD PTSD
}

\author{
1Zaujatul Amna and ${ }^{2} \mathrm{Hsiu}-\mathrm{Chen}$ Lin \\ ${ }^{1}$ Department of Psychology of Medicine Faculty, Syiah Kuala University, Indonesia. \\ ${ }^{2}$ Department of Psychology in Counseling and Clinical Psychologist, Asia Univeristy, Taiwan \\ Email: amnazaujatul@gmail.com
}

Received: Sep 27, 2015

Accepted: Jan 14, 2016

Published: May 28, 2016

Article Url: https://journal.scadindependent.org/index.php/jipeuradeun/article/view/96

\begin{abstract}
This study investigated the effectiveness of psycho-education methods on college students' attitudes toward post traumatic stress disorder. Analysis of results indicated that lecturing was the most effective psycho-educational method to obtain attitudinal changes. The effects of psycho-education methods of a shortduration intervention for college students' positive attitudes toward PTSD. Findings from the study led to the results that a short-duration of psychoeducation intervention on PTSD effectively increases college students' attitudes toward post traumatic stress disorder, reduces negative attitudes towards PTSD.
\end{abstract}

Keywords: Psychoeducation Methods, PTSD, Students 


\section{A. Introduction}

Aceh is the most western province of Indonesia, and has a history of traumatic events since 1976 to 2012. It started with a conflict situation; Aceh has been a site of militarized conflict, claiming fighting for Free Aceh Movement, demanding independence from the Indonesian government. On December 26, 2004, Aceh was devastated by an earthquake and tsunami. Aceh was the scene of a bloody separatist conflict for decades before the government signed a peace pact with the rebels in 2005. The semi-autonomous province has been generally peaceful since the signing of the pact and a former rebel leader was elected governor in 2006, but sporadic violence had occurred in recent years. On December 2, 2011, four people were killed in two separate armed attacks on New Year's Eve in Indonesia's Aceh province. On January 10, 2012, a 7.3 Richter scale earthquake hit waters off Banda Aceh, Indonesia (Al-Chaidar, 1999, \& Jakarta Pos, 2012).

This event may involve the threat of death to oneself or to someone else, or to one's own or someone else's physical or psychological integrity. The impact of post-disaster is closely associated with mental health of the individual, both for victims and non-victims. When a person experiences a traumatic event, it is common to experience some of symptoms in the immediate aftermath as part of a normal reaction to severe stress (Priscilla, 2007; DSM, 2000). Traumatic events such as natural disaster, tsunami, earthquake, social violence; rapes and assaults, wars, accidents and predatory violence confront people with such horror and threat that it may temporarily or permanently alter their capacity to cope, their biological threat perception and attitude, and their concepts of themselves and conditions (Corrigan, 2004).

Rosebloom and William (2010) stated the psychological responses to disaster includes acute stress disorder, generalized anxiety disorder, panic disorder, major depressive disorder, brief psychotic disorder, alcohol abuse or dependence substance abuse, Post Traumatic Stress Disorder (PTSD) and etc. Once a person better understands a condition they feel more in control of the situation and this in turn reduces the psychological problems associated with 
it. One such therapy uses psycho-education, psycho-education interventions should be part of the standard therapy for patients with mental health (APA, 2000; Oflaz., Hatipoglu., \& Aydin, 2008). Psycho-education will provide information to the participants, utilizing handouts or books supplemented by verbal discussions. It is important to understand about attitudes toward posttraumatic stress disorder and possible factors which might have led to the formation of these attitudes.

\section{B. Method}

1. Design

A quasi-experimental research design was adopted to present the study; a structured questionnaire titled as attitudes toward post-traumatic stress disorder scale (At-PTSD's scale) developed by the researcher was administered.

\section{Participants}

Students in different majors in Syiah Kuala University in Banda Aceh City, Indonesia, were recruited as research participants among 22 departments. The subjects were 121 students of different departments including; department of Nurse, Education, Architecture, and Psychology. The total sample of participants $100 \%$, Acehnese $100 \%$ all single, and all Islam (Muslim). Sixty one (50.4\%) participants were male and sixty (49.6\%) participants were female and participated in the study for pretest and posttest. Thirty-two (26.4 \%), participants were from Department of Nurse, Thirty participants (24.8\%) were from Department of Education, Thirty participants $(24.8 \%)$ were from department of Architecture, and Twenty-nine (24\%) participants were from department of Psychology. Education levels of the participants were $100 \%$ first year. Participants ranged in age from 18 to 20 with mean age of $18.73(\mathrm{SD}=.719)$.

\section{General Procedure}

Participants were divided into three experimental groups and one control group. Three experimental groups received different psychoeducation methods including handout, lectures, and interactive discussion, while the control group did not receive any treatment. Since the procedure 
is described in detail in the earlier report, only a brief description of it will be presented here. Researcher invited a coworker, the clinical psychologists with expertise in the relevant field. The purpose of this was to ensure participants fully understood about the material of PTSD.

Firstly, Handouts (treatment I). In this group, participants will read some information by themselves. Secondly, lectures (treatment II). In this group the lecture method defined as an intervention which provides information about post- traumatic stress disorder. Psychoeducation delivered via face-to-face lectures and handouts or notes. Thirdly, interactive discussion (treatment III). Design and develop interactive discussion which delivers information that can be offered as the primary or complimentary part of a broader intervention, that will included interactive discussion, lectures, handout and sharing section about post-traumatic stress disorder. Fourth, Control group. The participants have no exposure and were tested only in the generalization situation; participants are control, no treatment administered.

\section{Research Finding}

For the material, Taylor's (2006) clinician's guide to PTSD textbook was used either in handout and presentation in the experimental groups. The intervention focus on providing factual information about PTSD to the participants. The At-PTSD scale a standardized tool which measure attitudes toward post traumatic stress disorder consisted five subscales with five point likert scale is employed ranging from "strongly disagree" (scored as 1) to "strongly agree" (scored as 5). Before researcher run a Cronbach"s alpha on scale items or item analysis of At-PTSD's scale, researcher tried to reverse code items that are negatively worded so that a high value indicates the same type of response on every item.

\section{Test re-tests reliability of At-PTSD scale between pre-test and post-test score.}

In phase one of the analyses, the total of Cronbach's alpha, posttest was higher than pre-test scores. The post-test score was $a=.941$ and pre-test score was $\mathrm{a}=.902$. 
2. One-way ANOVA differences score for pre-test and post-test

A one-way ANOVA test was performed to see if there were any statistical differences of attitudinal changes for college students before and after received psychoeducation program. Table 1 show results of one-way ANOVA that group differences were significant scores the pre-test and post-test, $\mathrm{F}$ value between group were $[\mathrm{F}(3,117)=34.436, p=.000]$ and the result showed was differences homogeneity of variance in difference score of pre-test and post-test with Levene's test for equality of variances, the significance of Levene's test is .623 was larger than a $(p=.05)$. Researcher assumed that there was a statistically significant difference on college students' attitude toward PTSD, and the results showed was differences homogeneity of variance in difference score of pre-test and post-test. By indicating significant differences score among of handout, lecture, interactive discussion and control group, with levene's test for equality of variances, the significance of levene's test is .623 was larger than a $(p=.05)$, assume that the variability in difference score of two conditions was not significantly different. Table 1 showed the result one-way ANOVA:

Table 1. One-way ANOVA differences score pre-test and post-test groups

\begin{tabular}{llcccc}
\hline & Measure & $\begin{array}{c}\text { Sum of } \\
\text { Square }\end{array}$ & Df & $\begin{array}{c}\text { Mean } \\
\text { Square }\end{array}$ & F \\
\hline $\begin{array}{l}\text { score pre- } \\
\text { post test }\end{array}$ & Between & 40518.07 & 3 & 13506.02 & \\
& $\begin{array}{l}\text { Groups } \\
\text { Within groups }\end{array}$ & 43369.04 & 117 & 370.68 & $36.436^{* *}$ \\
& Total & 83887.11 & 120 & & \\
\hline${ }^{* * p}<<.01$ & & & & &
\end{tabular}

\section{Homogeneous subset scores}

Table 2 showed that lecture and interactive discussion groups are grouped together because they do not differ from each other. While, control group also grouped with handout group because do not differ from each other, but are different to group 1 and 2 . 
Table 2. Homogeneous subset between pre-test and post-tes

\begin{tabular}{llll}
\hline Measure & Group & \multicolumn{2}{l}{ Subset for alpha $=0.05$} \\
\cline { 2 - 4 } & & 1 & 2 \\
\hline Pre-posttest & Lecture & -13.07 & 24.69 \\
& $\begin{array}{l}\text { Interactive } \\
\text { discussion } \\
\text { Control }\end{array}$ & -10.47 & 24.88 \\
& Handout & & \\
\hline Sig. & & .964 & 1.000 \\
\hline
\end{tabular}

*"Uses harmonic mean sample size $=30.212$

\section{Paired sample t-test}

Test a paired sample t-test indicated that score were significantly higher among groups on the effects of psycho-educational method on college students' attitudes toward PTSD. The pairs of handout reported that was significantly $(M=24.875, S D=16.439), \mathrm{t}(31)=8.56, p<.005$. Lecture method reported was significant, the mean scores pre-test and post-test was statistically significant higher $(\mathrm{M}=-13.067, \mathrm{SD}=21.496), \mathrm{t}(29)=-3.329$, $p<.005$. While, interactive discussion group reported was significant higher $(\mathrm{M}=-10.467, \mathrm{SD}=17.828), \mathrm{t}(29)=-3.216, p<.005$, and the control showed was statistically significant $(\mathrm{M}=24.690, \mathrm{p}<.005), \mathrm{t}(28)=6.325$. The second hypothesis was rejected and concludes that was significant among experimental groups but the psycho-education methods didn't approved because lecture method had higher score than the interactive discussion and handout.

\section{Comparing each subscale among group}

The analysis of each subscale to find out the effects of psychoeducational method on college students' attitudes toward post-traumatic stress disorder based one four different methods, handout, lecture, interactive discussion, and control group. The comparison across groups used the difference score pretest and posttest of each subscales for authoritarianism, benevolence, social restrictive, community mental health ideology, and interpersonal ideology across among group for handout - lecture - interactive discussion - control group. 


\section{One-way ANOVA for Each Subscale of at-PTSD}

The results of one-way ANOVA indicate that each subscale in difference score were significant $(p>0.05)$. The result presents in the table 3 below:

Table 3. One-way ANOVA across four groups in difference score Pre-test and Post-test

\begin{tabular}{|c|c|c|c|c|c|c|}
\hline $\begin{array}{l}\text { Subscale score } \\
\text { pre-post test }\end{array}$ & $\begin{array}{l}\text { Levene } \\
\text { statistic }\end{array}$ & Measure & $\begin{array}{l}\text { Sum of } \\
\text { Square }\end{array}$ & df & $\begin{array}{l}\text { Mean } \\
\text { Square }\end{array}$ & $\mathrm{F}$ \\
\hline \multirow[t]{3}{*}{ Authoritarianism } & $3.48^{*}$ & $\begin{array}{l}\text { Between } \\
\text { groups }\end{array}$ & 3070.102 & 3 & 1023.367 & $43.187^{* *}$ \\
\hline & & Within groups & 2772.46 & 117 & 23.696 & \\
\hline & & Total & 5842.562 & 120 & & \\
\hline \multirow[t]{3}{*}{ Benevolence } & .728 & $\begin{array}{l}\text { Between } \\
\text { groups }\end{array}$ & 4003.735 & 3 & 1334.578 & $57.608^{* *}$ \\
\hline & & Within groups & 2710.463 & 117 & 23.166 & \\
\hline & & Total & 6714.198 & 120 & & \\
\hline \multirow[t]{3}{*}{ Social restrictive } & .765 & $\begin{array}{l}\text { Between } \\
\text { groups }\end{array}$ & 2416.176 & 3 & 805.392 & $37.620^{* *}$ \\
\hline & & Within groups & 2504.799 & 117 & 21.409 & \\
\hline & & Total & 4920.98 & 120 & & \\
\hline \multirow{3}{*}{$\begin{array}{l}\text { Community } \\
\text { mental health } \\
\text { ideology }\end{array}$} & .495 & $\begin{array}{l}\text { Between } \\
\text { groups }\end{array}$ & 1287.03 & 3 & 429.01 & $16.197^{* *}$ \\
\hline & & Within groups & 3098.97 & 117 & 26.487 & \\
\hline & & Total & 4386 & 120 & & \\
\hline \multirow[t]{3}{*}{$\begin{array}{l}\text { Interpersonal } \\
\text { ideology }\end{array}$} & .366 & $\begin{array}{l}\text { Between } \\
\text { groups }\end{array}$ & 1608.2 & 3 & 536.065 & $25.892^{* *}$ \\
\hline & & Within groups & 2422.366 & 117 & 20.704 & \\
\hline & & Total & 4030.56 & 120 & & \\
\hline
\end{tabular}

\section{Discussion}

The purpose of the experiments presented above was to provide quantitative data on the benefits of various group psycho-education formats so that researcher can make informed decisions about the better design to delivery of PTSD information. Reliability of At-PTSD's scale post-test was higher than pre-test, post-test coefficient reliability a $=0.941$ while for the pre-test $\mathrm{a}=0.902$,

The first study hypothesis concerned the effects of psychoeducation for pre-test and post-test for experimental groups and control 
group. The psycho-educational intervention yielded benefits for the participants in attitudes toward post-traumatic stress disorder after the psycho-educational intervention.

A one-way ANOVA showed a statistically significant difference in the study, which means that psycho-education method, changes the attitudes toward post-traumatic stress disorder. This finding corroborates with the previous research that psycho-educational interventions have consistently been found to impact positively and reduce relapse rates in individuals with mental disorders (Gearing, 2008). However, psychoeducation has been found to be effective in increasing awareness of mental health symptoms, such as PTSD, depression, and psychological distress (Hess et. al., 2004; Oflaz, Hatipoglu., \& Aydin, 2008; Honey, Bennett., \& Morgan, 2002; Hayes., \& Gantt, 1992; Wessley, Bryant, Greenberg, Earnshaw, Sharpley., \& Hughes, 2008).

The second goal of the study was to examine significant differences on college students' attitudes toward post-traumatic stress disorder among 3 different methods, interactive discussion $>$ lecture $>$ handout. Paired sample test differences showed that of all the treatment of this study in the 3 groups between post-test and pre-test showed were a statistically significance difference in prevalence among 3 experimental groups. Comparing how a group of subjects perform in two different test methods, the result showed that mean scores of treatment in third groups, only means of 2 groups, lecture and interactive discussion treatment had a higher scores, which meant that lecture and interactive discussion were more effective within the experimental groups.

Psycho-education offered in lecture and interactive discussion groups for participants can be helpful in increasing attitudes toward PTSD which means that participants who received including lecture and interactive discussion group of psycho-education reported improvements in their attitudes toward PTSD. Lecture treatment was more effective to changes the attitudes toward PTSD on college students, all-inclusive power point presentations in the class combined with handouts. In endeavors to pack as much information in a lecture as possible and to 
make easier for the students. The author concluded that the method had been effective in changes participants' attitudes, while reducing levels of negative attitudes for those people with PTSD. This finding provides evidence that psycho-education methods with lecture can be an effective method for those participants that changes the attitudes toward PTSD.

Unfortunately, in this research the second hypothesis was not approved, as researcher predicted interactive discussion treatment would be a better design for psycho-education groups, but the results of this study did not indicate such, interactive discussion treatment was not entirely applicable to the present study. The possible reason why interactive discussion treatment cannot be an effective method of psychoeducation, as most participants in this study have a long-term memories about traumatic events, for participants who have experienced posttraumatic stress disorder it's difficult to share deeply about experience in a group, also for those people who do not know each other or haven't established a circle of trust, it's difficult for them to share and discuss indepth. According to Norris, Tracy, \& Galea (2009) people with posttraumatic stress disorder will avoid thoughts, feeling, or discussions of reminders and difficulty expressing feelings. People who have a traumatic experience that was of chronic dysfunction, those people don't recover from the impact of the disaster but maintains a high level of reaction over time. This also indicates that it is necessary to note how to control the quality of intervention in such a small sample. Handout group also was not entirely applicable to the present study, because the post-test score was higher than pre-test. It is possible that psycho-education attempts may not have been optimally successful because they did not integrate information about PTSD on the handout.

In this study first researcher analyze then total score then each subscale score. The results showed that the similarity with the total score, lecture method was more effective for those participants than interactive discussion and also significant difference on attitudes toward PTSD. From each subscale participants showed that authoritarianism, benevolence, community mental health ideology and interpersonal ideology. 
Unfortunately, in social restrictive subscale, participants have negative attitudes toward PTSD. Negative attitudes and a lack of understanding can cause people with mental health problems to be treated badly or labeled in a way that hurts their standing in the community. On social restrictive subscale, participants decreased the attitudes toward PTSD. The possibly, mobility restrictions caused by experiences of stigmatization, attitude, perception about PTSD and by discomfort in 'normal' society outside the attitudes toward PTSD were more important.

\section{E. Conclusion}

Findings from this study suggest that a psycho-educational method-based intervention was effective in increasing college students' attitudes toward post-traumatic stress disorder. In conclusion of this research study it can be seen that there was strong and direct relationship between psycho-education and positive attitudes toward PTSD. To our knowledge, this is the first study on the implementation and effectiveness of a standard psycho-education program on college students' attitudes toward post-traumatic stress disorder in Banda Aceh.

In regards to attitudes toward PTSD, while there were decreases in the desire for social restrictive in the school community, the increase in views of dangerousness and unpredictability is of some concern and points to the need for psycho-education to address these aspects of attitude towards those mental disorders. The social restrictive subscales in certain areas were low which strongly indicates need for longer psychoeducation prevention to increase the attitudes toward PTSD. This study has several limitations. The improvements in the psycho-educational intervention burden were confirmed for a relatively short period, for two weeks it's not enough, compared to other studies with a follow-up duration of one year (Karanci, 2004). Therefore, further studies are needed to confirm the long-term effects on college students, the psychoeducational interventional should be given more time in order to achieve better results. 


\section{Bibliography}

American Psychiatric Association. (2000). Diagnostic and statistical manual of mental disorders: DSM-IV-TR. Washington, DC: American Psychiatric Publishing, Inc.

Cohen, J., \& Struening, E. L. (1962). Opinions about mental Illness in the personnel of two large mental hospital. Abnormal and Social Psychology, 64(5), 349-360.

Corrigan, P. (2004). How stigma interferes with mental health care. American Psychologist, 59(7), 614-625

Fatimatuzzahroh, F., Abdoellah, O. S., \& Sunardi, S. (2015). The Potential of Pesantren In Sustainable Rural Development. Jurnal Ilmiah Peuradeun, 3(2), 257-278.

Gearing, R. E. (2008). Evidence-Based Family Psycho-educational Interventions for Children and Adolescents with Psychotic Disorders. Can Acad Child Adolesc Psychiatry, 17(1), 2-11.

Hayes, R., \& Gantt, A. (1992). Patient psychoeducation: The therapeutic use of knowledge for the mentally ill. Social Work Heal th Care, 17, 53-67.

Hess, S. G., Cox, T. S., Gonzales, L. C., Kastelic, E. A., Mink, S. P., \& Rose, L.E. et. al. (2004). A survey of adolescens' knowledge about depression. Archives of Psychiatric Nursing, 18(6), 228-234.

Honey, K. L., Bennett, P., \& Morgan, M. (2002). A brief psycho-educational group intervention for postnatal depression. British Journal of Clinical Psychology, 41, 405-409.

Karanci, A. N. (2004). Caregivers of Turkish schizophrenic patients: Causal attributions, burdens and attitudes to help from the health professional. Social Psychiatry Psychiatr Epidemiol: 30(6): 261-268.

Norris, F., Tracy, M., \& Galea, S. (2009). Looking for resilience: Understanding the longitudinal trajectories of responses to stress. Social Science \& Medicine. 2190-2198.

Oflaz, F, Hatipoglu, S., \& Aydin, H. (2008). Effectiveness of psychoeducation intervention on post-traumatic stress disorder and coping styles of earthquake survivors. Journal of Clinical Nursing, 17. 677-687

Priscilla, D. B. (2007). A practical approach to trauma: Emprowering interventions. California, Thousand Oaks: Sage Publications, Inc. 
Rosenbloom, D., \& Williams, M. B. (2010). Life after trauma: a workbook for healing. ( $2^{\text {nd }}$ edition). Foreword by Pearlman, L. A. New York: The guilford press.

Salami, S. (2015). Implementing Neuro Linguistic Programming (NLP) in Changing Students' Behavior: Research Done at Islamic Universities in Aceh. Jurnal Ilmiah Peuradeun, 3(2), 235-256.

Taylor, S. (2006). Clinician's Guide to PTSD: A Cognitive-Behavioral Approach: Guilford Publications.

Wessley, S., Bryant, R., Greenberg, N., Earnshaw, M., Sharpley, J., \& Hughes, J. (2008). Does psychoeducation help prevent posttraumatic psychological distress? Psychiatry, 71, 287-307.

Yusoff, M. Z. M., \& Hamzah, A. (2015). Direction of Moral Education Teacher To Enrich Character Education. Jurnal Ilmiah Peuradeun, 3(1), 119-132.

ZA, T. (2014). Islamic Studies dalam Pendekatan Multidisipliner (Suatu Kajian Gradual Menuju Paradigma Global). Jurnal Ilmiah Peuradeun, 2(2), 211-234. 